\title{
STAND UP INDIA PROGRAMME - AN ADDRESS TO FINANCIAL PROBLEMS \\ OF MICRO AND SMALL SCALE MANUFACTURING
}

\section{AND PRODUCTION UNITS}

\author{
RAVI KUMAR \\ Assistant Professor, Department. of Management and Commerce, Amrita Vishwa Vidyapeetham, \\ Mysuru Campus, Karnataka, India.
}

\begin{abstract}
Skill India Programme, Startup India and Stand Up India programme are the buzz words of today in manufacturing, Production and Services sectors. As present government has taken the oath to inculcate skills in every youth and help them towards startups and establish their own enterprise and become owner of their own rather doing job with some other and intern help in employment and GDP development. It is also observed that SC/ST/Women categories are marginalized in this area since inception and it was the dream of Dr. B. R. Ambedkar that equal opportunities to be given to them also to grow and showcase their talents, ideas and ability to prove themselves as a successful entrepreneur, a person and citizen of India. The present study is to understand the progress of this program and its success. The results of the study state that nearly $70 \%$ of the units expressed positive growth and expressed that if financial support would have not been availed through this platform, it would be a dream to startup their own industries and women entrepreneurs also feel that they are more empowered and able to establish their identity.
\end{abstract}

KEY WORDS: Stand Up India, Finance, MSME, Manufacturing and Production Industries \& Women Entrepreneurs

Received: Dec 21, 2017; Accepted: Jan 12, 2018; Published: Feb 13, 2018; Paper Id.: IJMPERDFEB2018147

\section{INTRODUCTION}

\section{BACKGROUND}

'Industrialise or Perish' was the popular slogan which was coined by the outstanding Engineer Administrator, Bharat Ratna Sir. M. Visveswarayya.

The Indian economy is prospering through the process of creation of micro and small scale manufacturing units as it is the only medium through which it can address the global competition. The small and medium enterprises have been contributing since a long time to the expansion of entrepreneurial culture through its business innovations. The Micro and small scale production units are widely spread across different sectors of economy producing wide diversified series of products and services meeting the local and global demands of market. The contribution of theses units in GDP is around 6\%, in manufacturing sector it is around 33\% and contributes nearly $45 \%$ in exports. The below table No 1 shows the contribution that manufacturing and production sector is making in the economy, both in terms of manufacturing and services. 
Table 1: Share of MSME Sector in GDP and Total Manufacturing Output

\begin{tabular}{|c|c|c|c|c|c|c|c|c|}
\hline \multicolumn{4}{|c|}{ Manufacturing Output at current prices } & \multicolumn{5}{|c|}{$\begin{array}{c}\text { Share of MSME GVA to GVA/GDP at constant } \\
\text { price for base year } 2011-12(\%)\end{array}$} \\
\hline \multirow[b]{2}{*}{ Year } & \multirow{2}{*}{$\begin{array}{c}\text { MSME } \\
\text { Manufactu } \\
\text { ring } \\
\text { Output } \\
\text { 1(Rs.in } \\
\text { Crore) }\end{array}$} & \multirow{2}{*}{$\begin{array}{c}\text { Share of } \\
\text { MSME } \\
\text { Manufacturin } \\
\text { g Output in } \\
\text { total } \\
\text { Manufacturin } \\
\text { g Output }(\%)\end{array}$} & \multicolumn{2}{|c|}{$\begin{array}{l}\text { MSME Manu- } \\
\text { facturing Sector }\end{array}$} & \multicolumn{2}{|c|}{$\begin{array}{l}\text { MSME Services } \\
\text { sector }\end{array}$} & \multicolumn{2}{|c|}{ Total } \\
\hline & & & $\underset{\text { In }}{\text { GVA }}$ & In GDP & $\underset{\text { In }}{\text { GVA }}$ & $\underset{\text { GDP }}{\text { In }}$ & In GVA & $\begin{array}{l}\text { In } \\
\text { GDP }\end{array}$ \\
\hline 2011-12 & 2167110 & 33.12 & 6.64 & 6.16 & 25.66 & 23.81 & 32.29 & 29.97 \\
\hline $2012-13$ & 2385248 & 33.22 & 6.77 & 6.27 & 26.05 & 24.13 & 32.89 & 30.40 \\
\hline 2013-14 & 2653329 & 33.27 & 6.79 & 6.27 & 26.40 & 24.37 & 33.19 & 30.64 \\
\hline $2014-15$ & 2783433 & 33.40 & 6.63 & 6.11 & 26.72 & 24.63 & 33.34 & 30.74 \\
\hline
\end{tabular}

Source: MSME Annual Report 2016-17

Karnataka, one of the most fast grown state of South India with Information \& Technology as a main stream, since last 25 years. The state has also shown a remarkable growth in manufacturing sector along with IT sector. Ministry of Commerce and Industries with the help of local chambers of Commerce and business have been supporting the local manufacturing and production units towards establishment of new units, revival of sick industries and encouraging young rural entrepreneurs to be part of the industry. The table 2 shows the details of the number of units registered under MSME, investment made in and scope of employment they have enhanced.

Table 2: MSMEs Registered in Karnataka

\begin{tabular}{|c|c|c|c|}
\hline Year & $\begin{array}{c}\text { NUMBER } \\
\text { OF UNITS }\end{array}$ & $\begin{array}{c}\text { INVESTMENT } \\
\text { (Lakh Rs.) }\end{array}$ & EMPLOYMENT \\
\hline $2011-12$ & 21021 & 159641 & 28387 \\
\hline $2012-13$ & 24206 & 216851 & 155551 \\
\hline $2013-14$ & 25966 & 285056 & 167347 \\
\hline $2014-15$ & 19721 & 191905 & 122286 \\
\hline
\end{tabular}

Source: Directorate of Industries and Commerce

Mysuru district lies on the southern Deccan plateau, with watershed of Kaveri River. The district has majorly red soil and some parts of district are found with deep black soil, saline alluvo -colluvial soil and brown forest soil. The prime minerals resources are Magnesite, Limestone, Quartz, Graphite, Dunite and Dolomite. There are 8 Industrial areas and 6 Industrial estates in the district covering 4538 acres and 150.54 acres respectively. Total number of 28,932 MSMEs has been registered from 2005-2016 amounts to total investment of Rs. 64021 lakhs. The table 3 below narrates about the distribution of Micro and small enterprises in Mysuru District.

\section{Stand Up India Scheme}

Stand Up India is to promote entrepreneurs at grass root level for economic empowerment and job creation. It was launched to coincide with celebration of $125^{\text {th }}$ birth anniversary of Dr. B. R. Ambedkar to leverage the institutional credit to reach the underserved sector of people such as SC/ST and Women entrepreneurs so as to enable them to participate in the economic growth of the nation. 
Table 3: Details of Existing Micro and Small Enterprises and Artisan Units in Mysuru District

\begin{tabular}{|c|l|c|c|c|}
\hline $\begin{array}{c}\text { NIC } \\
\text { CODE } \\
\text { NO. }\end{array}$ & \multicolumn{1}{|c|}{ TYPE OF INDUSTRY } & $\begin{array}{c}\text { NUMBER OF } \\
\text { UNITS }\end{array}$ & $\begin{array}{c}\text { INVESTMENT } \\
\text { (Lakh Rs.) }\end{array}$ & EMPLOYMENT \\
\hline 20 & Agro Based & 38 & 1980 & 435 \\
\hline 23 & Cotton textile & 8 & 180 & 140 \\
\hline 24 & $\begin{array}{l}\text { Woolen, silk and artificial } \\
\text { Thread based }\end{array}$ & 42 & 228 & 435 \\
\hline 26 & $\begin{array}{l}\text { Ready- made garments and } \\
\text { embroidery }\end{array}$ & 36 & 458 & 312 \\
\hline 27 & $\begin{array}{l}\text { Wooden/Wooden based } \\
\text { furniture }\end{array}$ & 174 & 1210 & 732 \\
\hline 28. & Paper and Paper products & 7 & 175 & 64 \\
\hline 29 & Leather based & 33 & 38 & 99 \\
\hline 31. & Chemical/Chemical based & 62 & 162 & 712 \\
\hline 32 & Rubber, Plastic and Petro based & 14 & 98 & 82 \\
\hline 33. & Mineral based & 9 & 92 & 76 \\
\hline 35. & Engineering units & 17 & 116 & 66 \\
\hline 36. & $\begin{array}{l}\text { Electrical Machinery and } \\
\text { transport }\end{array}$ & 12 & 214 & 18 \\
\hline 97. & Repairing and Servicing & 4 & 6 & - \\
\hline 01. & Others & 394 & - & \\
\hline
\end{tabular}

Source: DIC Mysore (As on 31.03.2016)

The object of the Stand Up India scheme is to facilitate bank loans between Rs10 lakhs to Rs 1 Crore to at least one SC/ST or Women entrepreneur per bank branch of all scheduled commercial banks for setting up a Greenfield enterprise. Stand Up India scheme give a tri-dimensional support through: 1. Handholding Support 2. Providing information on financing 3. Credit Guarantee.

Loans under the scheme are available for only Greenfield projects. Greenfield project means those are first time ventures of the beneficiary in the manufacturing or service or trading sector. In case of non-individual industrial units, 51\% of share should be owned by SC/ST or women entrepreneurs. It is a composite loan (term and working capital) between 10 lakhs to 100 lakhs for a lowest inter rate not exceeding Base Rate (MCLR+3\%+tenor premium). Beside primary security the loan may be secured by collateral security or guarantee of a credit guarantee fund scheme for stand up India loans (CGFSIL) as decided by the bank. Loans are repayable in 7 years. Working capital of Rs.10 lakhs may be sanctioned by way of cash credit. $10 \%$ of the minimum amount of the project cost has to be own contribution and difference of $15 \%$ to constitute $25 \%$ margin amount can be provided in convergence with eligible central/state government schemes.

\section{REVIEW OF LITERATURE}

\section{Finance Problems Faced by Micro and Small Industrial Units}

Manshani, Sapna\&Dubey, Anjna., (2017) stated that even after dramatically changes over the years towards women entrepreneurs, and investors look at women entrepreneur as co-founders, but still women startup face more obstacles as compared to men with starting and developing a business. Statistics state that funding that is done to women owned industries is comparatively low to that are owned by men. To overcome this woman has to show confidence and commitment to their ideas and produce a product that speaks on its own. 
MukeshLohar (2017) understands that enterprises based in Tier II and Tier III cities find more significantly difficult to procure the finance for their enterprises as compared to Tier I cities. He further states that this gravity differs from region to region of the country.

Prof. Mishu Tripathi.et.al., (2016) narrate dearth of easy finance and credit instruments. For growth of any enterprise, primary it is the quick finance that acts as critical growth factor. Observations state that many micros, small and medium enterprises start with minimal capital input, but subsequently at a certain point their growth is stagnating. This intern has an impact on GDP, Import and export and employment, in total economic growth. Some of important problem faced in obtain the credit assistance are; Complex collaterals required to obtain term loans, High transaction costs in imports/exports, Private Equity Funding is difficult to obtain, Banks offer high rates for term loans, Private equity (PE) dilutes control in the company, Un-standardized project appraisal system for term loans, Cumbersome procedures and delay in fund disbursement.

R. Gandhi (2015) state that the prime three factors play a considerable role in prolonging the financing delays and gaps to small and medium enterprises - The poor quality of projects seeking funding, the inability of MSMEs to make the best possible use of available resources of funding and the negative attitude displayed by MSMEs towards equity financing.

Pema Lama (2013) states about the lack of availability of adequate and timely credit from banks. Presently, high interest rates, the high risk perception among the banks, unreasonable collateral demand, restrictive and conditional working capital limits and huge procedural transaction cost often creates problems for the MSMEs in availing easy credit from the banks as it does not have any alternative sources of finance.

IFC (2012)A Research study report on needs, gaps and the way forward: Micro, small and medium enterprise finance in India states that the procedure for providing debt and equity form of capital financing to MSME is almost same as any other segments. But due to differentiated product and their different marketing strategies makes heterogeneity and high risk to finance these enterprises.

\section{Empowerment of Women Through Stand Up India Scheme}

AchantaShamith (2017)in his study states that through the stand-up initiative, a long term proposal has been made to improve the potential of women entrepreneurs to fuel economic growth and help build stronger communities globally. It is expected that this program will be an opportunity and entrepreneurial channel for motivated women to systematically work through their ideas and ultimately start their ventures.

Jharkhand Economic Survey (2016): The report states that the program has benefited 39 SC/ST beneficiaries and 152 women beneficiaries leading to the development of industrial units by the SC/ST community and empowers the women towards successfully establishing and running their enterprises.

\section{Objectives of the Study}

- To understand the financial problems faced by micro and small manufacturing and production industrial units.

- To examine how stand up India programme has addressed the financial problems faced.

- To study empowerment of women entrepreneurs through Stand up India Programme. 


\section{Hypotheses}

H1: Stand Up India program is able to address the financial problems faced by Micro

And Small manufacturing and production industrial units.

H2: Stand Up India Program has empowered women entrepreneurs.

\section{METHODOLOGY}

The study interview schedule is administered to collect the information according. Non -probability based convenience sampling method is adopted. The respondent to the questionnaire were the beneficiaries of the scheme. Chisquare tool is opted to test the hypotheses.

Table 4: Details of Respondents the Type of Enterprise and Caste They Belong

\begin{tabular}{|c|c|c|c|c|}
\hline $\begin{array}{c}\text { Type of Manufacturing/ } \\
\text { Production unit }\end{array}$ & Schedule caste & Schedule Tribes & $\begin{array}{c}\text { Women } \\
\text { Entrepreneur }\end{array}$ & Total \\
\hline $\begin{array}{c}\text { Ready-made garments and } \\
\text { embroidery }\end{array}$ & 3 & 2 & 5 & 10 \\
\hline $\begin{array}{c}\text { Wooden/Wooden based } \\
\text { furniture }\end{array}$ & 2 & 5 & - & 7 \\
\hline Leather based & 3 & 2 & 1 & 6 \\
\hline Engineering units & 2 & 1 & - & 4 \\
\hline Chemical/Chemical based & 1 & - & 1 & 2 \\
\hline $\begin{array}{c}\text { Woolen, silk and artificial } \\
\text { Thread based }\end{array}$ & - & $\mathbf{1 2}$ & $\mathbf{7}$ & $\mathbf{3 0}$ \\
\hline Total & $\mathbf{1 1}$ & &
\end{tabular}

\section{RESULTS AND DISCUSSIONS}

Finance is the key component of factors to production to any manufacturing units. Even though banks and financial institutions extend this facility, but it has its own constraints. The following results of the study and discussions help to understand how "Stand Up India" program is able to address and facilitate the selected manufacturing and production units selected around Mysore for the present study.

Table 5: Distribution of Respondents having Gained the Benefits of the Scheme

\begin{tabular}{|l|c|c|c|c|c|c|c|c|}
\hline \multicolumn{1}{|c|}{ Benefits of Stand Up Programme } & SC & \% & ST & \% & $\begin{array}{c}\text { Women } \\
\text { Entpr. }\end{array}$ & \% & N=30 & \% \\
\hline $\begin{array}{l}\text { Able to access to finance for require } \\
\text { amount }\end{array}$ & 9 & 82 & 11 & 92 & 5 & 72 & 25 & 84 \\
\hline Availed loan at low cost of capital & 11 & 100 & 12 & 100 & 7 & 100 & 30 & 100 \\
\hline $\begin{array}{l}\text { No security/mortgage helped to acquire } \\
\text { loan easily }\end{array}$ & 10 & 91 & 8 & 67 & 6 & 85 & 24 & 80 \\
\hline $\begin{array}{l}\text { Default Security by GCGS scheme has } \\
\text { boosted confidence to access loans }\end{array}$ & 8 & 72 & 7 & 59 & 4 & 58 & 19 & 64 \\
\hline $\begin{array}{l}\text { Moratium period has helped for better } \\
\text { financial management }\end{array}$ & 11 & 100 & 12 & 100 & 7 & 100 & 30 & 100 \\
\hline $\begin{array}{l}\text { Subsidy extension helps in better working } \\
\text { finance. }\end{array}$ & 11 & 100 & 12 & 100 & 7 & 100 & 30 & 100 \\
\hline $\begin{array}{l}\text { Handholding support has a positive help in } \\
\text { effective financial and project planning }\end{array}$ & 10 & 91 & 9 & 75 & 5 & 72 & 24 & 80 \\
\hline Scheme extents tax benefits & 11 & 100 & 12 & 100 & 7 & 100 & 30 & 100 \\
\hline
\end{tabular}




\begin{tabular}{|l|c|c|c|c|c|c|c|c|}
\hline \multicolumn{7}{|c|}{ Table 5: Contd., } \\
\hline $\begin{array}{l}\text { Scheme has helped towards non-financial } \\
\text { benefits also }\end{array}$ & 11 & 100 & 12 & 100 & 7 & 100 & 30 & 100 \\
\hline $\begin{array}{l}\text { Programme has led to high chance of } \\
\text { getting loans and better financial planning } \\
\text { and management. }\end{array}$ & 10 & 91 & 8 & 67 & 4 & 58 & 22 & 74 \\
\hline
\end{tabular}

Source: Field study

Above table clearly shows that in many aspects the programme is able to address the requirement of finance to manufacturing and production units. M. Madhushudan Rao (The Hindu. April 03, 2015) has addressed about the problems faced by SC/ST entrepreneurs and also stated that CGFT for SME units has addressed the financial problem with its credit protection policy. The present study highlight about GCGS a credit protection policy of programme agreed by bankers to protect against default it any. The table shows $84 \%$ of respondents agree that they were able to access the finance for their required amount. 100\% response for availing loan at low cost, Moratium period of 18 months extended, subsidy extension, tax benefits and non-financial guidance towards project proposal preparation, training on skill development has boosted to confidence to effective enterprise management. $64 \%$ respondents of opinion of credit protection and other disagreed. This might for the reason that they have to invest some initial amount for which there is no protection. $74 \%$ responded on overall say that the program has helped in getting financial assistance, setting and running up their manufacturing and production units effectively and successfully.

H0: Stand Up India program is not able to address the financial problems faced by Micro and Small manufacturing and production industrial units.

H1: Stand Up India programme is ableto address the financial problems faced by Micro and Small manufacturing and production industrial units.

\section{Test of Hypothesis}

Chi-Square test value is $13.53 \& 5.99$ is tabulated value for $5 \%$ level of significance.

\section{Results}

Since the calculated value of 13.53 is greater than the critical value of 5.99 @ $5 \%$ level of significance and 2 degree freedom the null hypothesis (H0) is rejected.

\section{Conclusions}

Stand Up India programme is able to provide platform to SC/ST/Women entrepreneurs to establish and develop their manufacturing and production units by helping in project planning and financial management in total.

Woman has always been the backbone of any household and a motivation and support of development of enterprises. In recent times, it is observed women is taking a front seat to start and run an enterprise on par with man and able succeed and contribute to family support also. Stand Up Indian is program is also set up to address and support the women entrepreneur and motivate, them to come up with new manufacturing and production, service units. The study reveals that the program is successful toward the same and intern has empowered them. The following table narrates how women empowerment is able to achieve through this program. The results of study states that on an average more than $70 \%$ success results have been the witnessed by the Stand Up India towards woman category. The program has not only 
helped to start up the venture by financial aid, but also have enhanced their status in society and empowered to keep up their ideas, abilities and words in this competitive world. $72 \%$ of the respondents state that now they have control their lives and decision and are free to participate in social gathering which were previously restricted to some events. Enhancement of skill and an opportunity to work with men force were possible with program. Increase in respect in family, relative and society is a prime achievement they have got which they were looking ahead is the response of $85 \%$ of the beneficiaries. Government and as a human being, every individual has to take care of the safer and comfortable working environment to women as still there are gaps, as only 53\% responses is seen positive. Giving equal opportunity and making women as a companion will definitely lead to a new entrepreneurial world.

Table 6: Women Empowerment Through of Stand Up Programme

\begin{tabular}{|l|c|c|}
\hline \multicolumn{1}{|c|}{ Women Empowerment Parameters } & N=7 & $\%$ \\
\hline Self-worth, respect and Dignity & 6 & 85 \\
\hline Control over their life and decisions & 5 & 72 \\
\hline $\begin{array}{l}\text { Participation in social, religious and public } \\
\text { activities }\end{array}$ & 5 & 72 \\
\hline Increase in social status & 6 & 85 \\
\hline Financial and Economic liberty & 7 & 78 \\
\hline Improvement in education/skill status & 5 & 72 \\
\hline $\begin{array}{l}\text { Equal opportunities to work with men without } \\
\text { any bias }\end{array}$ & 5 & 72 \\
\hline Safe and comfortable working environment & 4 & 53 \\
\hline
\end{tabular}

H0: Stand Up India Programme has not empowered women entrepreneurs.

H1: Stand Up India Programme hasempowered women entrepreneurs.

\section{Test of Hypothesis}

Chi-Square test value is $4.0281 \& 3.84$ is tabulated value for $5 \%$ level of significance.

\section{Results}

Since the calculated value of 4.0281 is greater than the critical value of $3.84 @ 5 \%$ level of significance and 1 degree freedom, the null hypothesis (H0) is rejected.

\section{Conclusion}

Women are to establish and develop their manufacturing and production units by help of Stand Up India Program and empower their status and existence in society and entrepreneurial world.

\section{SUMMARY AND CONCLUSIONS}

Stand Up India, with a vision to support and encourage SC/ST/Women to come up as entrepreneurs in manufacturing, services industries, is able to achieve its progress even though still it is a long way ahead to succeed. 
Finance being main aspect where everyone thinks twice to venture himself in the industry is being aided through this platform and this will have a long term leverage to industry and beneficiaries.

\section{REFERENCES}

1. Sapna,Mashani\&AnjnaDubey., (2017), Startup Women in startup India: A Study of Women entrepreneurs in India. Int.J. of Business and General Management., Vol.6, Issue4, Jan-Jul 2017; PP 91-100. ISSN (E): 2319-2275

2. AchantaShamith., (2017), Women Entrepreneruship: Start-Up Initiative and Digital India. $8^{\text {th }}$ International Conference on Recent Development in Engineering Science, Humanities and Management. PP 304-314 ISBN:978-93-86171-67-2

3. Mukesh, Lohar (2017): $\underline{\text { https://inc42.com/entrepreneurship/challenges-opportunities-indian-smbs }}$

4. Jharkahand Economic Survey Report - 2017

5. Upadhyay.et.al.,(2016) Economic Empowerment of Women through Skill Development and Entrepreneurship. Stand Up India -Entrepreneurship and Women Empowerment-Conference proceeding. PP365-369

6. S. L. Gupta \& R. Ranjan, Impact of Liberalization on Contribution of MSMES In Economic Development of India, International Journal of Business Management \& Research (IJBMR), Volume 4, Issue 4, July - August 2014, pp. 11-22

7. Prof.Mishu.Tripathi.et.al., (2016), Challenges faced by micro, small and medium enterprise sector in India. Int.J.of Science Technology and Management, Vo.5, Issue No.03, PP -69-77, March 2016. ISSN 2394-1537

8. R.Gandhi (2015), Credit Risk and Problem loan management, $\underline{\text { www.bis.org }}$

9. Chandraiah.R\&Vani.R., (2014) The Prospects and Problems of MSMEs secor in India an Analytical Study.Int.J.of Business and Management Invention. Vo.3, Issue 8 (Aug.2014). PP-27-40

10. Pema Lama., (2013)., Micro, Small and Medium Enterprises in India-Problems and Prospects. Business Studies- Vol.XXXIII (2013),PP-106-116

11. International Finance Corporation Report (2012) - A Research Study on Needs, Gaps and Way Forward.

12. www.dcmsme.gov.in

13. www.msme.gov.in Annual Report 2016-17 